\title{
Development Tactics for Farmer Specialized Cooperative in New Period
}

\author{
Manlin Zhang \\ College of Economy and Law, Bohai University, Jinzhou, 121013, China \\ 793143130@qq.com
}

Keywords: farmer specialized cooperative; effect; presence problems; development tactics

\begin{abstract}
Farmer specialized cooperative is the effective way to realize small farmers docking big market and improve the degree of organization of farmers, which has become the transformation of traditional agriculture to modern agriculture and to solve the problem of "three rural issues". Although farmer specialized cooperative maintain a rapid development momentum, but there is still a lack of ideological awareness, the development of blindness, lack of talent and funds, the Ministry of management is not standardized, and other issues. In order to solve these problems, need for the parties to continue their support from the aspects of policy, capital, environment, the specific strategies are: solve the funding difficulties, improve the decision-making mechanism, innovation incentive mechanism, interaction of internal and external conditions. The research content of this paper solves the key problems in the development of cooperatives, and plays an important role in promoting the construction of new countryside and realizing the healthy development of cooperatives.
\end{abstract}

\section{Introduction}

Farmer specialized cooperative contains similar agricultural products production operators or similar agricultural production and operation of service providers, users, voluntary union, democratic management ,is mutual aid economic organization which based on rural household contract management. Farmer specialized cooperative services to its main members, provides the purchase of agricultural production materials, sales, processing, transportation and storage of agricultural products and management technology, agricultural production and operation technology, information and other services. In order to support and guide the development of farmer specialized cooperative, regulate the organization and behavior of farmers' professional cooperatives, protect the legitimate rights and interests of farmers' professional cooperatives and their members, and promote the development of agriculture and rural economy, implement the "People's Republic of China farmers' Professional Cooperatives Act in 2007, provide legal protection for the healthy development of farmers' professional cooperation. However, most cooperatives are not standardized, there are a lot of problems in the development process. In view of the problems existing in the course of the development of farmers' professional cooperatives, this paper formulates the corresponding strategies to promote the further development of the farmers' professional cooperatives, in order to build a new socialist countryside.

\section{Effect of Farmer Specialized Cooperative}

The development of farmer specialized cooperative in new period, is not only to enhance the level of development of agricultural industrialization, promote advanced agricultural science and technology promotion, enhance market competition ability, cultivate peasant farmers democratic awareness and consciousness of cooperation, improve the degree of organization of farmers and an important means to increase the income of farmers, but also promote the rural construction in the new period, the development of production, affluent life, village clean, civilized, democratic management objectives of the effective carrier. The specific effects are as follows [1-3]:

(1) Promoting the development of agricultural production and increasing farmers' income. The new rural construction must adhere to the rural economic development as the center. The development of rural economy is the material guarantee for the realization of the well-off life, the 
rural wind civilization, the village capacity and the management of democracy. Farmer specialized cooperatives can effectively disperse capital, labor, land and market organization, solve the problem of joint small farmers and big market, enter the market with lower transaction costs, reduce transaction costs, increase the added value of agricultural products, and increase the income.

(2) Promoting agricultural science and technology promotion, improving the quality of farmers. The development of modern agriculture cannot do without science and technology, the essence of modern agriculture is the application of modern biotechnology, information technology, environmental technology and modern management technology, to realize the agricultural production of "high quality, high yield, efficient, ecological and safe". The main body of agricultural science and technology promotion is the majority of farmers, farmers' cooperatives can through laboratory teaching, scientific demonstration and guidance, dissemination of new technologies, new information and new achievements, improving farmers' production skills and comprehensive quality.

(3) Promoting the comprehensive reform of rural areas and the mode of government services. Promoting the reform of the rural comprehensive system needs to solve the problems of agricultural investment mechanism, land scale management, collective economic management and the construction of rural grass-roots organizations. Farmer professional cooperatives can implement industrial policies and support measures to reduce the production of blindness and disorder. The government obtains the real and reliable agricultural production and marketing, science and technology and policy information through the farmer specialized cooperative society, enhances the government to the agriculture and the rural economy regulation and control effectiveness.

(4) Cultivation of farmers' democratic consciousness and cooperative consciousness. Farmer specialized cooperative is a voluntary union, democratic management mutual aid economic organization, the biggest characteristic is the farmer is founded, the farmer management and the farmer benefit. The members of the cooperatives and economic interests are closely related, the majority of the members of the direct involvement in the cooperative economic organization of production and management, and supervision practice, democratic management exercise, gradually enhance the sense of participation, awareness of democracy and supervision, common development through cooperation to achieve personal interests and collective interests.

\section{Presence Problems of Development of Farmer Specialized Cooperative}

Although Farmer specialized cooperative maintains the momentum of rapid development, the rural economic development has a certain role, but there are still some problems, which restricts the further development of farmers' professional cooperatives, we must pay enough attention. The main problems are as follows [4-6]:

(1) Ideological understanding is not in place. Farmer specialized cooperative is an important transformation of agricultural production relations, which provides an effective carrier for the construction of rural areas, promote the development of modern agriculture, increase farmers' income and realize common prosperity.

(2) Blind development tendency. Under the support of the government, the rapid growth in the number of cooperatives, but at the same time some do not have the conditions for the establishment of cooperatives also bred. Some local government officials for performance factors, the blind pursuit of quantity under the jurisdiction of regional cooperative growth, causing some cooperative funds, no organization management regulations and offices, only by an application report written by the business sponsor, will be the competent authorities or local government approval, and in the business sector registered, can not reach for farmers service and help to increase the income of the peasants.

(3) Lack of talent and capital. The development of professional cooperatives requires a large number of talents, including business management personnel and professional and technical personnel. Many managers lack of experience, by virtue of their subjective organization of farmers. Lack of technical personnel, new technologies and new products are difficult to promote, can not play the role of science and technology in the first productivity. Shortage of funds to hinder the size 
of professional cooperatives, limited capacity, can not be supported by the financial sector credit. Due to the lack of a sound structure and the lack of supervision mechanism, the ability to attract industrial and commercial funds is limited.

(4) Internal management is not standardized. Pay attention to construction, light management, internal management and operation mechanism is not standardized, becomes a common problem of farmers' professional cooperatives. Although " People's Republic of China farmer cooperatives" put forward specific requirements, but in actual operation, can not be implemented in accordance with the law of democratic decision-making and democratic management, distribution system is not in place, to a certain extent, dampen the enthusiasm of the members. Members of cooperatives and simply trade relations, in a loose management condition, do not become a benefit sharing and risk sharing community.

\section{Development Tactics for Farmer Specialized Cooperative}

There are many problems in the development of farmer specialized cooperative, which are far from the requirements of the rural construction in the new era, which needs to continue to support the policy, funds, environment and so on. In combination with the relevant research results [7-11], this paper proposes the following development strategies, promote the development of farmers' professional cooperatives and the construction of new rural services.

(1) Solving the difficult financial difficulties. Funding is one of the difficult problems that puzzle the development of the farmer specialized cooperative, and it needs the joint efforts of the cooperatives, the financial sector and the relevant government departments. Cooperatives themselves should improve the financing mechanism, the development of scientific funds accumulation system. Encourage members of capital investment, establish a scientific mechanism of surplus distribution, taken in accordance with the transaction amount and its method of combining the distribution of profits, the best combination of fairness and efficiency; government supervision and coordination in the process of financing, to create a good financing environment, the expansion of financial funds to support efforts to expand the scale of special funds. Focus on supporting the introduction of new varieties and new technology promotion and brand cultivation etc.. Encourage and support the local guide guarantee institutions to provide loan guarantees for cooperatives, cooperatives will explore into the scope of agricultural insurance policy; financial institutions to provide financial services for the full range of cooperatives, cooperatives into the scope of the credit rating, and the relevant government departments jointly establish credit files for the financial agency, the corporate credit cooperatives and the members of the monomer credit together, the establishment of agricultural loans Easy Access. Innovative financial products and services to meet the needs of cooperatives, explore the scope of the use of cooperatives to guarantee loans for cooperatives, innovative types of loans in accordance with the provisions of the law and the actual needs of the loan species.

(2) Improving the decision-making mechanism. In the process of standard development of farmer specialized cooperative, with external development conditions gradually improved, as a member of the farmers' professional cooperatives can become the subject of interest, fully promote democracy, the whole process of decision making, supervision and management for members to participate in cooperative. Members' economic interests in the cooperatives can be protected, whether the democratic rights can be guaranteed, and further improve the decision-making mechanism will be the key to promote the standardized operation and sustainable development of cooperatives. A major decision by the members of the general assembly, according to the cooperative function and purpose and legal requirements, members of the general assembly is the highest authority of cooperatives, major issues decided by the members of the general assembly, decision-making and management of all members can participate in the general meeting of members of the cooperatives; Daily decisions by the Council, the Council members perform their duties in Congress authorized by the chairman and the Council is the principal-agent relationship, the decision-making power authorized according to the size, reasonable division of power limits of the general meeting of members, Council, chairman of the explicit authorization between relations; 
specific operation by the management is responsible for, by members of the peasant consciousness and restrictions the quality of their own culture, if the specific management of cooperatives are democratic decision-making, will waste a lot of time and energy, is not a guarantee of scientific decision-making. Managers are responsible for the day-to-day management of the professional cooperatives can be truly conducive to the development of ordinary members of the democratic management awareness. Improve the common members of cooperatives and core members of the gap in resources, enhance the homogeneity between members.

(3) Innovation incentive and restraint mechanism. Incentive and restraint mechanism, that is, the subject of incentive and restraint in accordance with the organization's objectives, the law of human behavior, through a variety of ways, the power to inspire people, make people have an inherent power and requirements, burst out of enthusiasm, initiative and creativity, and regulate people's behavior, advancing towards the desired goal of the main incentive. How to mobilize the enthusiasm of people is the eternal theme of human resource development and management. To achieve through a series of human activities in the development of farmer cooperatives, how to use various means of management and control, to induce the excitation of the behavior, is the primary problem of management, incentive and restraint mechanism is one of the main means of management. Innovative incentive mechanism needs to be considered from the perspective of investors, managers and members. The incentive for investors, in addition to the limited by shares, mainly reflected in the infrared, the additional voting rights, this is a manifestation of control right incentive mechanism; the ideal of management incentives is given a certain residual claim, managers return directly and cooperatives performance management can not only promote the hook. Their hard work, but also a powerful guarantee for sustainable development of cooperatives. The members of the incentive should not only embody in by shares, should also be reflected in the right to the use of resources and professional technology training and the right to participate in the democratic management right of cooperatives, the members have a sense of belonging; "restraint mechanism" means to regulate the behavior of organization members, to facilitate the orderly operation, give full play to. Its effect is the requirement of specification and standard rules and means through legal procedures enacted and promulgated the implementation of the. Constraints include the state's laws and regulations, industry standards, internal rules and regulations, as well as various forms of supervision, etc.

(4) Internal motivation and external conditions of interaction. Internal cause is the fundamental cause of the development of things and internal power, external factors are the conditions for the development of things, external factors play a role through the internal. In the field of development of farmers' professional cooperatives, internal causes can be understood as internal motivation, external factors can be understood as external conditions. The internal forces and the internal logic of the development of farmer cooperatives, economic benefits is the core power for the development of cooperatives, the establishment of farmer cooperatives, is in order to obtain more economic benefits and achieve common prosperity. In the village collective economic organizations as the basis to ensure the dominant position of farmers, farmers' voluntary participation, free exit, mutual benefit, joint agreement total business workers, better reflect the basic characteristics of farmers and the dominant position of public ownership. With the characteristic industry to promote the cooperative development of the rural collective economy support, relying on the advantages of resources, focus on the cultivation of characteristic industry, the competitive advantage of industries; improve the internal governance structure is the development of cooperatives internal security, the formation of the internal governance structure of benefit sharing, democratic management, capital accumulation and risk sharing in combination, to ensure the healthy development of farmer cooperatives; professional cooperatives is one of the best form to improve the rural collective economy as the basis of the two-tier management system, depends on the external conditions fundamentally improve the internal system of rules is the key to the healthy development of cooperatives at present. Talent is the first resource for the development of cooperatives in talent cultivation and introduction of technology as the guide, create a good cultural atmosphere and environment; policy support is the key to the healthy development of cooperatives, with the support 
of policy and strategic planning as the basis, construction of financial, tax and credit insurance, as one of the efficient policy support system. Laws and regulations is the fundamental guarantee for the healthy development of cooperatives, to improve the law and establishing the system of guarantee, creating good environment of law and system, formulate related local laws and regulations, improve the sharing of benefits and risks "as the core of the property rights incentive system and income distribution system; government services and market mechanism the healthy development of cooperatives" booster "of government services and market regulation organically, and jointly promote the healthy development of farmer cooperatives.

\section{Conclusion}

The establishment and development of farmer specialized cooperatives has become the basic way to realize the transformation from traditional agriculture to modern agriculture and to solve the problems of " three rural Issues ". The construction of socialist new countryside and developing modern agriculture is facing many new problems, embodies the organization of collective action for the farmers mutual development, farmers' income growth, lack of stamina insufficient rural public service etc.. How to make the scattered small farmers access to market information, achieve docking with the market in the production and management, establish organization operation mechanism of low cost and high efficiency, has become the new rural construction and the development of modern agriculture to be solved. The development strategy proposed in this paper has important theoretical and practical significance for promoting the development of farmer specialized cooperatives.

\section{References}

[1] Y. F. Tong, "On the problems and measures of farmers' professional cooperatives," Farmers to get rich, vol. 60, no. 2, pp. 13-13, 2016.

[2] J. B. Pang, L. F. Deng, L. L. Fan, "Financing difficulties, causes and solutions of specialized farmer cooperatives in Heilongjiang Province," Research of Agricultural Modernization, vol. 37, no. 4, pp. 725-732, 2016.

[3] L. Wei, "Research summary problems and countermeasures for construction of new socialist countryside", Review of Economic Research, vol. 33, no. 2, pp. 47-57, 2014.

[4] Q. Bingchun, J. Xizai, "Current situation, problems and development countermeasures of farmer specialized cooperatives in Jilin province", Taxation and Economy, vol. 34, no. 5, pp. 108-112, 2012.

[5] H. Jinhua, "Research on the development model of farmer specialized cooperative in Zhejiang province", Master's degree of Zhejiang agriculture and forestry university, 2013.

[6] L. Tengjun, "Study on the operation mode of farmer specialized cooperative", Master's degree of Sichuan agricultural university, 2013.

[7] L. N. Niu, "The problems and solutions in the development of farmers' professional cooperatives," Rural practical science and technology information, vol. 22, no. 4, pp. 10-10, 2016.

[8] L. Lina, L. Tao, "Research on Excitation and constraint of mechanism for farmer specialized cooperative", Journal of Hunan University of Science and Engineering, vol. 35, no. 1, pp. 97-99, 2014.

[9] Q. Yang, Y. Y. Tong, "Research on the construction of the 'Trinity' accounting supervision system of farmers' professional cooperatives," Agricultural Economy, vol. 36, no. 8, pp. 68-70, 2016.

[10] W. Wan, "Practical problems and countermeasures on development of farmer specialized cooperative", Economic Review, vol. 30, no. 11, pp. 63-66, 2014.

[11] L. X. Han, "Development Countermeasures of Ningxia farmers' professional cooperatives," Journal of Anhui Agricultural Sciences, vol. 44, no. 19, pp. 238-239, 2016. 